\title{
Raw soya-bean flour increases cholecystokinin release in man
}

\author{
BY JOHN CALAM, JOANNA C. BOJARSKI \\ AND CAROLINE J.SPRINGER \\ Department of Medicine, Royal Postgraduate Medical School, Hammersmith Hospital, \\ Ducane Road, London W12 OHS
}

(Received 15 December 1986 - Accepted 7 April 1987)

\begin{abstract}
1. The aim of the present study was to determine whether oral ingestion of raw soya-bean flour, which contains trypsin inhibitors, alters the release of cholecystokinin (CCK) in man.

2. Eleven healthy volunteers ate two mixed meals: one with raw soya-bean flour and the other with soya-bean flour that had been heat-treated. The two flours inhibited 34 and $3 \mathrm{mg}$ trypsin/g flour respectively.

3. CCK was measured in plasma using a bioassay based on the release of amylase $(E C$ 3.2.1.1) from dispersed rat pancreatic acini.

4. The peak CCK response was 16.8 (SE $8 \cdot 1$ ) pmol/1 with raw soya-bean flour but 4.9 (SE $2 \cdot 8$ ) pmol/1 with heattreated flour $(P<0.05)$.

5. We conclude that ingestion of raw soya-bean flour increases CCK release in man and that heat treatment which reduces the trypsin inhibitor content of the flour also diminishes its CCK-releasing effect.
\end{abstract}

Cholecystokinin (CCK) is released from the jejunum and stimulates pancreatic enzyme secretion (Baile et al. 1986). The release of CCK is inhibited by intraduodenal trypsin providing negative feedback control of enzyme secretion (Ihse et al. 1977; Slaff et al. 1984; Owyang et al. 1986). Soya beans contain trypsin inhibitors (Whitaker \& Feeney, 1973; Rackis \& Gumbmann, 1981; Wilson, 1981) and increased plasma CCK concentrations have been demonstrated in rats fed on raw soya-bean meal (Adrian et al. 1982; Liddle et al. 1984). CCK also stimulates pancreatic growth (Folsch et al. 1978). Prolonged ingestion of such a diet produces pancreatic hypertrophy (Booth et al. 1964), adenomas, and adenocarcinomas (McGuinness et al. 1980) and an increased susceptibility to carcinogens (Morgan et al. 1977; Levison et al. 1979; McGuinness et al. 1984) in rats. These effects lead to the suggestion (Levison et al. 1979; Adrian et al. 1982; Liener, 1986) that the recent massive increase in soya-bean ingestion in the Western world (Wolf \& Cowan, 1975) has contributed to the concomitant rise in the incidence of carcinoma of the pancreas (Young et al. 1978). However, several lines of evidence appear to provide reassurance. Soya bean trypsin-inhibitor activity is diminished by cooking (Rackis \& Gumbmann, 1981; Wolf \& Cowan, 1975) and by incubation with human gastric juice (Krogdahl \& Holm, 1981). Soyabean trypsin inhibitors have also been reported to have less effect on human trypsin compared with rat trypsin (Temler et al. 1983). We therefore examined the effects of raw and heat-treated soya-bean flour on meal-stimulated CCK release in man.

\section{METHODS}

The present study was approved by the Hospital Ethics Committee and eleven normal subjects (24-37 years) took part. Subjects fasted overnight, then ate $5 \mathrm{~g}$ soya-bean flour mixed with $40 \mathrm{~g}$ apple sauce (Rowntree Mackintosh, Hyde, Cheshire) every $30 \mathrm{~min}$. After

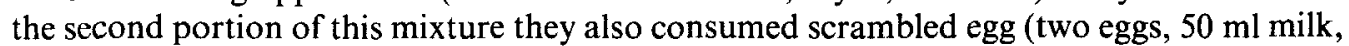
$20 \mathrm{~g}$ margarine) and coffee (1.65 g Nescafé (Nestlé, Croydon, Surrey), $25 \mathrm{ml}$ milk, $175 \mathrm{ml}$ water). This protocol was used to provide fresh inhibitor throughout digestion of the meal, because of the time-dependent inactivation of soya-bean trypsin-inhibitor by gastric juice 
(Krogdahl \& Holm, 1981). Each subject was studied twice, using raw soya-bean flour (Bredsoy; Spillers, Ware, Dorset) on one day and heat-treated soya-bean flour (Trusoy; Spillers) on the other, in random order. The trypsin-inhibitor activity of the two flours was estimated by the method of Kakade et al. (1969).

Blood was withdrawn from an arm vein into chilled tubes containing aprotinin (2000 $\mathrm{kIU} / \mathrm{ml}$ blood $)$ and EDTA $(10 \mathrm{nmol} / \mathrm{l}$ blood $)$ and plasma was stored at $-20^{\circ}$. Plasmas were prepared for bioassay as described by Liddle et al. (1984). Brieffy, CCK peptides were extracted by passing $6 \mathrm{ml}$ plasma through Waters Sep-pak C18 cartridges (Millipore, Harrow, Middlesex) and eluted in a mixture of $800 \mu \mathrm{l}$ ethanol, $198 \mu \mathrm{l}$ water and $2 \mu \mathrm{l}$ trifluoroacetic acid. The eluates were dried in siliconized tubes under nitrogen at $45^{\circ}$. CCK activity was measured by incubation for $30 \mathrm{~min}$ with dispersed rat acini, prepared by collagenase ( $E C$ 3.4.24.3) digestion, as described by Gardner \& Jensen (1985). The amylase (EC 3.2.1.1) released from the unknown samples was measured using the Phadebas kit (Pharmacia, Uppsala, Sweden) and compared with the release obtained with CCK8 standards.

The assay has a detection limit of $3 \mathrm{pmol} / 1$ and the coefficient of variation of triplicates within the assay was $11 \%$. The coefficient of variation for basal amylase release was $29 \%$, determined on eight different days, and the coefficient of variation for amylase release from acini incubated with CCK $8,30 \mathrm{nmol} / 1$, was $21 \%$, measured on eight different days. In view of this interassay variability all samples from each subject were processed in the same bioassay.

Gastrin was measured by radioimmunoassay using antibody 1611 (Rosenquist \& Walsh, 1980) and neurotensin by radioimmunoassay using C-terminal antibody NT58 (Lee et al. 1984).

Statistical analysis employed Wilcoxon's matched-pairs test, and $P<0.05$ was taken to be significant.

\section{RESULTS}

The rise in plasma CCK after the meal was greater and more sustained when the meal was given with raw soya-bean flour (Bredsoy) than when the soya-bean flour had been cooked (Trusoy) (Fig. 1). There were no statistically significant differences between the postprandial rises in plasma gastrin (mean peak gastrin rise (pmol/1): 19 (SE 7) with raw flour and 24 (SE 8) with cooked flour) or neurotensin (raw flour 24 (SE 7), cooked flour 30 (SE 10)) on the two study days. Bredsoy and Trusoy inhibited 34 and $3 \mathrm{mg}$ of bovine trypsin/g flour respectively.

\section{DISCUSSION}

In the present study normal subjects ingested soya-bean flour which was either raw or had received heat-treatment which destroyed about $90 \%$ of trypsin-inhibitor activity. The plasma CCK response to a mixed meal was substantially greater during ingestion of raw flour than with heat-treated flour. Although we cannot be certain, it seems likely that the heat-labile factor responsible was soya-bean trypsin-inhibitor. The magnitude of the CCK response in the presence of heat-treated flour was similar to human postprandial responses reported by others using the same bioassay system (Liddle et al. 1985; Owyang et al. 1986). The postprandial rise in plasma CCK concentration was followed by a second smaller rise, as recorded by others (Byrnes et al. 1981; Himeno et al. 1983). We believe this to be the first demonstration of increased CCK release associated with administration of raw soyabean flour in man. Gastrin and neurotensin release were unaltered, suggesting that there was no generalized change in gut hormone release.

In the present study, raw soya-bean flour had no significant effect on CCK release until the egg meal was also given. This contrasts with the marked effects of soya-bean trypsin- 


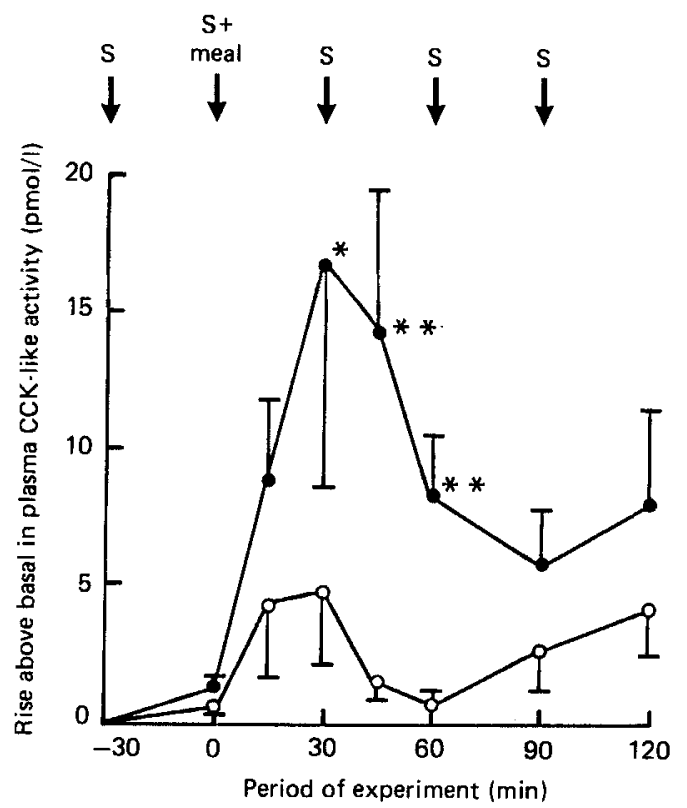

Fig. 1. The effect of eating raw (O) or heat-treated $(O)$ soya-bean flour at the times indicated (S) on plasma cholecystokinin (CCK)-like activity following a scrambled-egg meal. Values are means, with their standard errors represented by vertical bars, for eleven subjects. ${ }^{*} P<0.05,{ }^{* *} P<0.01$.

inhibitor and trypsin on basal pancreatic secretion in the rat (Green \& Lyman, 1972). It is possible that the buffering capacity of our egg meal preserved the flour from $\mathrm{pH}$-dependent degradation in the stomach. However, there may be a more fundamental difference between responses in rat and man because Owyang et al. (1986) found that soya-bean trypsin-inhibitor and trypsin do not affect basal CCK release in man, even when infused directly into the duodenum.

CCK has a number of physiological and pharmacological effects (Baile et al. 1986) and raw soya-bean products could be used to increase CCK release for therapeutic purposes. For example, CCK induces satiety resulting in diminished food intake in man (Baile et al. 1986) so that diets containing raw soya-bean might be used to stimulate CCK release in obesity. Animals fed on raw soya-bean meal fail to gain weight although impaired digestion of protein may also contribute to this effect (Booth et al. 1964; Whitaker \& Feeney, 1973; Rackis \& Gumbmann, 1981; Struthers et al. 1983).

However, before considering such applications there is a need to assess the potential hazards. Chronic ingestion of raw soya-bean meal produces pancreatic hypertrophy in chicks (Garlich \& Nesheim, 1966), pigs (Yen et al. 1977) and rats (Booth et al. 1964), plus benign and malignant tumours (McGuinness et al. 1980) and an increased susceptibility to carcinogens (Morgan et al. 1977; Levison et al. 1979; McGuinness et al. 1984) in the rat. These changes in animals have raised the possibility of a link between the recent increases in human soya-bean ingestion and pancreatic cancer in the Western world (Levison et al. 1979; Adrian et al. 1982; Liener, 1986).

Soya-bean products are indeed widely used in the Western diet. Soya-bean-based sauces and meat substitute are used in many products and soya-bean flour is used in bread and cakes. The soya-bean in these foods is either heat-treated by the manufacturer or cooked later to inactivate most but not all the trypsin-inhibitor present (Liener, 1986). It is reassuring to note that the process used by the manufacturer (Spillers) was sufficient to 
diminish CCK release as well as trypsin-inhibitor activity. Some 'health foods' such as soya-bean bran contain raw soya-bean but are not eaten extensively.

At present there is no direct evidence that raw soya-bean, trypsin inhibitors or CCK produce pancreatic hypertrophy or neoplasia in man. Folsch et al. (1984) found no change in the maximal pancreatic secretion rate of patients with chronic pancreatitis fed on $30 \mathrm{~g}$ raw soya-bean flour three times daily for 6 weeks. However, chronic pancreatitis might limit the organ's capacity to grow so that such a study does not exclude the possibility of a trophic effect on the normal human pancreas.

Trypsin inhibitors are widespread in nature and present in some traditional foods including apple, potato and egg (Whitaker \& Feeney, 1973; Rackis \& Gumbmann, 1981 ; Wilson, 1981). They include the Kunitz inhibitor which is inactivated by heat and by gastric juice and the Bowman-Birk inhibitor which survives in both situations (Wolf \& Cowan, 1975; Krogdahl \& Holm, 1981; Liener, 1986). The former predominates in soya-beans but the Bowman-Birk inhibitor is the major inhibitor present in ground nuts (Arachis hypogaea), chick peas (Cicer arietinum), lima beans (Phaseolus lunatus), adzuki beans ( $P$. angularis) and mung beans (P. aureus) (Wilson, 1981).

CCK-releasing factors such as those present in raw soya-bean may play a physiological role in meal-stimulated CCK release. They provide some interesting therapeutic possibilities but possible harmful effects of long-term ingestion have not been excluded.

We thank the Medical Research Council and the Wellcome Trust for financial support, and our subjects for taking part. We are grateful to Mr K. J. Collinge and Mr A. G. Croft of Spillers Premier Products (Ware, Dorset) for providing the soya-bean flours and for measuring their trypsin-inhibitor activity, and to Dr Walsh and Professor Bloom for gastrin and neurotensin antisera.

\section{REFERENCES}

Adrian, T. E., Pasquali, C., Pescosta, F., Bacarese-Hamilton, A. J. \& Bloom, S. R. (1982). Gut 23, A889.

Baile, C. A., McLaughlin, C. L. \& Della-Fera, M. A. (1986). Physiological Reviews 66, 172-234.

Booth, A. N., Robbins, D. J., Ribelin, W. E., De Eds, F., Smith, A. K. \& Rachis, J. J. (1964). Proceedings of the Society of Experimental Biology and Medicine 116, 1067-1069.

Byrnes, D. J., Henderson, L., Borody, T. \& Rehfeld, J. F. (1981). Clinica Chimica Acta 111, 81-89.

Folsch, U. R., Winckler, K. \& Wormsley, K. G. (1978). Scandinavian Journal of Gastroenterology 13, 663671 .

Folsch, U. R., Oldendorp, A., Lankish, P. G. \& Creutzfeldt, W. (1984). European Journal of Clinical Investigation 14, Suppl., 45.

Gardner, J. D. \& Jensen, R. T. (1985). Methods of Enzymology 109, 64-69.

Garlich, J. D. \& Nesheim, M. C. (1986). Journal of Nutrition 88, 100-110.

Green, G. M. \& Lyman, R. L. (1972). Proceedings of the Society of Experimental Biology and Medicine 140, 6-12.

Himeno, S., Tarui, S., Kanayama, S., Kuroshima, T., Shinomura, Y., Hayashi, C., Tateishi, K., Imagawa, K., Hashimura, E. \& Hamaoka, T. (1983). American Journal of Gastroenterology 78, 703-708.

Ihse, I., Lilja, P. \& Lundquist, I. (1977). Digestion 15, 303-308.

Kakade, M. L., Simons, N. \& Liener, I. E. (1969) Cereal Chemistry 40, 518-526.

Krogdahl, A. \& Holm, H. (1981). Journal of Nutrition 111, 2045-2051.

Lee, Y. C., Allen, J. M., Uttenthal, L. O., Walker, M. C., Shemilt, J., Gill, S. S. \& Bloom, S. R. (1984). Journal of Clinical Endocrinology and Metabolism 59, 45-50.

Levison, D. A., Morgan, R. G. H., Brimacombe, J. S., Hopwood, D., Coghill, G. \& Wormsley, K. G. (1979). Scandinavian Journal of Gastroenterology 14, 217-224.

Liddle, R. A., Goldfine, I. D. \& Williams, J. A. (1984). Gastroenterology 87, 542-549.

Liddle, R. A., Goldfine, I. D., Rosen, M. S., Taplitz, R. A. \& Williams, J. A. (1985). Journal of Clinicial Investigation 75, 1144-1152.

Liener, I. E. (1986). Journal of Nutrition 116, 920-923.

McGuinness, E. E., Morgan, R. G. H., Levison, D. A., Frape, D. L., Hopwood, D. \& Wormsley, K. G. (1980). Scandinavian Journal of Gastroenterology 15, 497-502. 
McGuinness, E. E., Morgan, R. G. \& Wormsley, K. G. (1984). Environmental Health Perspectives 56, 205212.

Morgan, R. G. H., Levison, D. A., Hopwood, D., Saunders, J. H. B. \& Wormsley, K. G. (1977), Cancer Letters 3, 87-90.

Owyang, C., Louie, D. S. \& Tatum, D. (1986). Journal of Clinical Investigation 77, 2042-2047.

Rackis, J. J. \& Gumbmann, M. R. (1981). In Antinutrients and Natural Toxicants in Foods, pp. 203-238. [R. L. Ory, editor]. Westport, Connecticut: Food and Nutrition Press.

Rosenquist, G. L. \& Walsh, J. H. (1980). In Gastrointestinal Hormones, pp. 769-795. [G. B. J. Glass, editor). New York: Raven Press.

Slaff, J., Jacobson, D., Tillman, R., Curington, C. \& Toskes, P. (1984). Gastroenterology 87, 44-52.

Struthers, B. J., MacDonald, J. R., Dahlgren, R. R. \& Hopkins, D. T. (1983). Journal of Nutrition 113, 86-97.

Temler, R. S., Simon, E. \& Amiguet, P. (1983). Enzyme 30, 105-114.

Whitaker, J. R. \& Feeney, R. E. (1973). Toxicants Occurring Naturally in Foods, pp. 276-298. Washington DC: National Academy of Sciences.

Wilson, K. A. (1981). In Antinutrients and Natural Toxicants in Food, pp. 187-202 [R. L. Ory, editor]. Westport, - Connecticut: Food and Nutrition Press.

Wolf, W. J. \& Cowan, J. C. (1975). Soybeans as a Food Source. Boca Raton, Florida: CRC Press.

Yen, J. T., Jensen, A. H. \& Simon, J. (1977). Journal of Nutrition 107, 156-165.

Young, J. L. Jr, Asine, A. J. \& Pollock, E. S. (1978). SEER program. Cancer Incidence and Mortality in the United States 1973-1976. Bethesda: US Department of Health Education \& Welfare. 